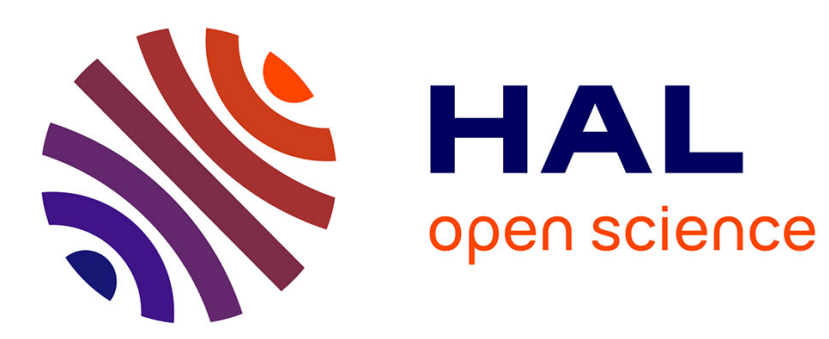

\title{
Hormone therapy and risk of venous thromboembolism among postmenopausal women
}

\author{
Marianne Canonico, Pierre-Yves Scarabin
}

\section{To cite this version:}

Marianne Canonico, Pierre-Yves Scarabin. Hormone therapy and risk of venous thromboembolism among postmenopausal women. Climacteric, 2009, 12 (s1), pp.76-80. 10.1080/13697130903006837 . inserm-01142910

\section{HAL Id: inserm-01142910 https://www.hal.inserm.fr/inserm-01142910}

Submitted on 16 Apr 2015

HAL is a multi-disciplinary open access archive for the deposit and dissemination of scientific research documents, whether they are published or not. The documents may come from teaching and research institutions in France or abroad, or from public or private research centers.
L'archive ouverte pluridisciplinaire HAL, est destinée au dépôt et à la diffusion de documents scientifiques de niveau recherche, publiés ou non, émanant des établissements d'enseignement et de recherche français ou étrangers, des laboratoires publics ou privés. 


\title{
Hormone therapy and risk of venous thromboembolism among postmenopausal women
}

\author{
Marianne Canonico and Pierre-Yves Scarabin \\ Inserm Unit 780, Cardiovascular Epidemiology Team, Hôpital Paul Brousse, \\ 16 avenue Paul Vaillant Couturier, 94807 Villejuif Cedex, France \\ email: marianne.canonico@inserm.fr
}

\begin{abstract}
Venous thromboembolism, either deep vein thrombosis or pulmonary embolism, is a serious side-effect of postmenopausal hormone therapy. Current use of oral estrogens increases the risk of venous thromboembolism, especially during the first year of treatment, but past users of hormone therapy have a similar risk as never users. Among women at high risk for venous thromboembolism (thrombogenic mutations, obesity,...), oral estrogens use further enhances the thrombotic risk. Recent studies showed that transdermal estrogens might be safe with respect to thrombotic risk. The difference in thrombotic risk between oral and transdermal estrogens may be partially explained by changes in haemostasis. Few data are currently available regarding the impact of progestogens on venous thromboembolism risk, but norpregnanes derivatives might be thrombogenic. Individual assessment of the benefit-risk ratio is needed before initiating a treatment and oral estrogens should be avoided among women at high risk for venous thromboembolism.
\end{abstract}

Key words: Venous thromboembolism, postmenopausal hormone therapy, route of estrogen administration, progestogens 


\section{Introduction}

Despite recent data showing that overall health risks may exceed benefits from hormone therapy ${ }^{1}$, many women remain eligible for this treatment. Women are mainly prescribed hormone therapy to treat postmenopausal climacteric symptoms. In addition, hormone therapy prevents osteoporosis. Harmful effects of hormone therapy include breast cancer and venous thromboembolism ${ }^{2}$. Furthermore, randomised controlled trials showed that hormone therapy might increase the risk of coronary heart disease and stroke 1,3 .

Most previous studies of venous thromboembolism in hormone therapy users were done in USA among women using conjugated equine estrogens alone or combined with medroxyprogesterone acetate ${ }^{1}, 3$. These results cannot be extrapolated to other types of hormone therapy used in Europe and especially to transdermal estrogens alone or combined with micronized progesterone. The purpose of this review is to report the data on the risk of venous thromboembolism among hormone therapy users, taking into account the route of estrogen administration as well as the clinical background.

\section{Incidence of venous thromboembolism}

Venous thromboembolism is an uncommon disease before the menopause. Its incidence markedly rises with increasing age after the menopause and reaches 1 per 100 over 75 years ${ }^{4}$. Venous thromboembolism commonly arises as a deep vein thrombosis but can also occur as a pulmonary embolism. Venous thrombosis may cause significant disability and/or death and, therefore, it is an important contributor to the burden of cardiovascular disease among postmenopausal women. Risk factors for venous thromboembolism include genetic background (thrombogenic mutation, protein deficit) and constitutional factors (overweight, obesity) but hormone use is also an important determinant of venous thromboembolism in women. 
Route of estrogen administration: a key point in reducing the risk of venous thromboembolism?

Clinical data

Since the 90's, observational studies done in majority in Anglo-Saxon countries have shown that oral estrogens increased the risk of venous thromboembolism among postmenopausal women. Few years later, randomized controlled trials confirmed the increased thrombotic risk among oral estrogens users. A recent meta-analysis has shown that thrombotic risk increased by more than two times among oral estrogens users ( $O R=2.5 ; 95 \%$ $\mathrm{Cl}$ : 1.9-3.4 and $\mathrm{OR}=2.1 ; 95 \% \mathrm{Cl}$ : 1.4-3.1 from observational studies and clinical trials, respectively) ${ }^{5}$.

The risk of venous thromboembolism among oral estrogens users may be modulated by the characteristics of hormone therapy. The thrombotic risk is significantly higher for treatment within the first year than for treatment of more than a year but past users have a similar thrombotic risk than never users. No significant difference in the risk of venous thromboembolism is observed between users of oral estrogens alone and oral estrogens plus progestogen ${ }^{5}$.

For many years, the association of venous thromboembolism with transdermal estrogens has not been a mainstream topic for clinical investigations and early results did not show a differential impact of oral and transdermal estrogens on thrombotic risk. The ESTHER (EStrogen and THromboEmblism Risk) study, a French case/control study of venous thromboembolism, has been the first to establish a differential impact of hormone therapy on thrombotic risk by route of estrogen administration. This study has shown that transdermal estrogens might be safe with respect to thrombotic risk while oral estrogens increased this risk ${ }^{6}$. Although based on few data, a meta-analysis of epidemiological studies has recently shown an odds ratio for thrombosis close to one in transdermal estrogen users as compared with non-users $\left(\mathrm{OR}=1.2,95 \% \mathrm{Cl}\right.$ : 0.9-1.7) ${ }^{5}$. These results from observational studies need to be confirmed, especially in randomized controlled trials. 


\section{Biological data}

The impact of estrogens by route of administration on haemostasis has been investigated in randomised controlled trials which results are consistent with clinical data. Biological evidence lends support to the elevated thrombotic risk among users of oral estrogens and to the difference between estrogens by route of administration.

Among oral estrogens users, there is clear evidence for an increase in plasma levels of markers for in-vivo thrombin activation (prothrombin fragment $1+2$ ) and lowered antithrombin activity in postmenopausal women, whereas transdermal estrogens have little or no effect on coagulation and fibrinolysis 7 . In addition, oral estrogens significantly decrease total protein $\mathrm{S}$ plasma level ${ }^{8}$. Activated protein $C$ (APC) resistance has emerged as a risk factor for venous thrombosis ${ }^{9}$. Although this phenotype is mostly related to a single mutation in the factor V gene (R506Q or Leiden mutation) ${ }^{10}$, APC resistance detected in the absence of any thrombogenic mutation is also an independent risk factor for venous thromboembolism ${ }^{11}$. An acquired resistance to activated protein $\mathrm{C}$ has been found in users of oral estrogens ${ }^{12}$, but randomised trials have recently showed that these results did not apply to users of transdermal estrogens ${ }^{13}$. Changes in prothrombin fragment $1+2$ plasma level are positively and significantly correlated with changes in ETP-based APCsr in factor $\mathrm{V}$ Leiden non-carriers allocated to oral estrogens. These biological data show that oral estrogens induce an APC resistance and activate blood coagulation, but these deleterious effects on coagulation do not apply to transdermal estrogen. These results emphasize the potential importance of the route of estrogen administration in prescribing estrogens.

\section{Progestogens: another important determinant of the thrombotic risk}

The impact of the progestogens on the risk of venous thromboembolism has been hardly studied among women using hormone therapy. Final results of the ESTHER study have shown an increase in the risk of venous thromboembolism among users of norpregnane derivatives (nomegestrol acetate or promegestone). However, micronized progesterone or pregnane 
derivatives were not associated with an increased thrombotic risk ${ }^{14}$. These results have just been confirmed by the data from the E3N study which also suggest a deleterious effect of nortestosterone derivatives on thrombotic risk 15. These data come from observational studies which are subject to bias and the results must therefore be cautiously interpreted. They need to be confirmed, especially in randomised controlled trials.

Data regarding the progestogen effects on haemostasis are scarce. However, randomised controlled trials have shown no change in haemostasis in women using transdermal estrogens combined with micronized progesterone ${ }^{7}, 13$. These results lend a biological support to the potential safety of micronized progesterone. Investigations regarding the impact of norpregnane derivatives on coagulation are ongoing.

\section{Hormone therapy in women at high risk for venous thromboembolism: advantages for transdermal estrogens}

The risk of venous thromboembolism increases with age and elevated bodymass index. Factor V Leiden mutation and prothrombin G20210A mutation are also important thrombotic risk factors. Few data regarding the impact of hormone therapy among women at high thrombotic risk are available.

\section{Thrombogenic mutations}

Factor V Leiden mutation and prothrombin G20210A mutation are the two most common genetic defects associated with an increased thrombotic risk ${ }^{5}$. Their prevalence is close to $5 \%$ and $2 \%$ respectively in a Caucasian population. Some studies have investigated the combination of a prothrombotic mutation and oral estrogen use on the risk of venous thromboembolism. Using the non-users without any mutation as the reference group, oral estrogens users who carry one prothrombotic mutation represent a group at high thrombotic risk ${ }^{5}$. In 2005, the ESTHER study gave the opportunity to investigate the impact of hormone therapy by route of estrogen administration and prothrombotic mutations on the risk of venous thrombosis. 
These results have shown for the first time that transdermal estrogens did not confer an additional risk on women with a mutation ${ }^{16}$.

\section{Overweight and obesity}

The impact of elevated body-mass index on thrombotic risk has been studied alone and together with oral estrogens use. Already twofold increased in women with an elevated body-mass index, the risk of venous thromboembolism is further enhanced among oral estrogens users with an overweight ${ }^{5}$. However, results from the ESTHER study have recently shown that transdermal estrogens did not increase the thrombotic risk among women with an overweight or obesity ${ }^{17}$.

\section{Hormone therapy and venous thromboembolism: individual genetic susceptibility}

Some enzymes including cytochromes $\mathrm{P} 450$ are implicated in the sex hormone metabolism and can modulate the estrogens biodisponibility. However, whether or not the impact of hormone therapy on thrombotic risk depends on genetic polymorphisms of these enzymes remains unclear. The ESTHER study has recently provided data regarding the impact of cytochromes P450 3A5 (CYP3A5) and 1A2 (CYP1A2) genetic polymorphisms on the association of venous thromboembolism with hormone therapy. Data analysis showed a synergism between $C Y P 3 A 5^{\star} 1$ allele and oral estrogen use on the risk of venous thromboembolism. Oral estrogen users who carry CYP $3 A 5^{*} 1$ allele could define a subgroup at high thrombotic risk. By contrast, transdermal estrogens appear safe with respect to thrombotic risk and do not interact with CYP3A5 genetic polymorphism ${ }^{18}$.

\section{Clinical implications, conclusions and perspectives}

Hormone replacement therapy can improve the quality of life for women with hypo-oestrogenic symptoms ${ }^{19}$ but exposes to harmful effects including venous thromboembolism. Pulmonary embolism accounts for about one third 
of the excess incidence of potentially fatal events associated with long term hormone therapy ${ }^{2}$. Therefore, the risk of venous thromboembolism is an important determinant of the benefit-risk profile of hormone therapy, and differences in the risk of venous thromboembolism between types of hormone therapy may have important clinical implications. In addition, since recent guidelines recommend that women are prescribed the lowest effective dose of hormone therapy for the shortest time possible, pulmonary embolism becomes a main adverse effect owing to oral estrogens therapy within the first year of treatment ${ }^{20}$. In contrast, there is little increase in the risk of stroke and breast cancer within the first year of treatment. Therefore, reducing the risk of venous thromboembolism by using transdermal estrogens could improve the benefit-risk profile of hormone therapy, especially among women at high risk of venous thromboembolism.

Future randomised trials will clarify this apparent safety of transdermal estrogens with respect to thrombotic risk. Clinical research should continue into genetic factors influencing the risk associated with hormone therapy, different estrogen and progestogen formulations, different modes of delivery, lower dose options, and alternative regimens (for example, selective oestrogen receptor modulators, phytoestrogens). Such research will assist patients and clinicians in making treatment decisions on the basis of an individual's benefits and risks ${ }^{21}$.

Conflict of interest: The authors report no conflicts of interest. The authors alone are responsible for the content and writing of the paper

\section{References}

[1] Rossouw JE, Anderson GL, Prentice RL, LaCroix AZ, Kooperberg C, Stefanick ML, et al. Risks and benefits of estrogen plus progestin in healthy postmenopausal women: principal results From the Women's Health Initiative randomized controlled trial. Jama. 2002 Jul 17;288(3):321-33.

[2] Beral V, Banks E, Reeves G. Evidence from randomised trials on the longterm effects of hormone replacement therapy. Lancet. 2002 Sep 21;360(9337):942-4.

[3] Anderson GL, Limacher M, Assaf AR, Bassford T, Beresford SA, Black H, et al. Effects of conjugated equine estrogen in postmenopausal women with 
hysterectomy: the Women's Health Initiative randomized controlled trial. Jama. 2004 Apr 14;291(14):1701-12.

[4] Oger E. Incidence of venous thromboembolism: a community-based study in Western France. EPI-GETBP Study Group. Groupe d'Etude de la Thrombose de Bretagne Occidentale. Thromb Haemost. 2000 May;83(5):657-60.

[5] Canonico M, Plu-Bureau G, Lowe GD, Scarabin PY. Hormone replacement therapy and risk of venous thromboembolism in postmenopausal women: systematic review and meta-analysis. Bmj. 2008 May 31;336(7655):1227-31.

[6] Scarabin PY, Oger E, Plu-Bureau G. Differential association of oral and transdermal oestrogen-replacement therapy with venous thromboembolism risk. Lancet. 2003 Aug 9;362(9382):428-32.

[7] Scarabin PY, Alhenc-Gelas M, Plu-Bureau G, Taisne P, Agher R, Aiach M. Effects of oral and transdermal estrogen/progesterone regimens on blood coagulation and fibrinolysis in postmenopausal women. A randomized controlled trial. Arterioscler Thromb Vasc Biol. 1997 Nov;17(11):3071-8.

[8] Marque V, Alhenc-Gelas M, Plu-Bureau G, Oger E, Scarabin PY. The effects of transdermal and oral estrogen/progesterone regimens on free and total protein $\mathrm{S}$ in postmenopausal women. Thromb Haemost. 2001 Aug;86(2):713-4.

[9] Dahlback B. Resistance to activated protein C caused by the factor VR506Q mutation is a common risk factor for venous thrombosis. Thromb Haemost. 1997 Jul;78(1):483-8.

[10] Bertina RM, Koeleman BP, Koster T, Rosendaal FR, Dirven RJ, de Ronde H, et al. Mutation in blood coagulation factor $\mathrm{V}$ associated with resistance to activated protein C. Nature. 1994 May 5;369(6475):64-7.

[11] de Visser MC, Rosendaal FR, Bertina RM. A reduced sensitivity for activated protein $\mathrm{C}$ in the absence of factor $\mathrm{V}$ Leiden increases the risk of venous thrombosis. Blood. 1999 Feb 15;93(4):1271-6.

[12] Hoibraaten E, Mowinckel MC, de Ronde H, Bertina RM, Sandset PM. Hormone replacement therapy and acquired resistance to activated protein $\mathrm{C}$ : results of a randomized, double-blind, placebo-controlled trial. $\mathrm{Br} \mathrm{J}$ Haematol. 2001 Nov;115(2):415-20.

[13] Oger E, Alhenc-Gelas M, Lacut K, Blouch MT, Roudaut N, Kerlan V, et al. Differential effects of oral and transdermal estrogen/progesterone regimens on sensitivity to activated protein $\mathrm{C}$ among postmenopausal women: a randomized trial. Arterioscler Thromb Vasc Biol. 2003 Sep 1;23(9):1671-6.

[14] Canonico M, Oger E, Plu-Bureau G, Conard J, Meyer G, Levesque H, et al. Hormone therapy and venous thromboembolism among postmenopausal women: impact of the route of estrogen administration and progestogens: the ESTHER study. Circulation. 2007 Feb 20;115(7):840-5.

[15] Canonico M, Fournier A, Carcaillon L, Olié V, Plu-Bureau G, Oger E, et al. Hormone therapy and venous thromboembolism : Early results from the E3N prospective study.: Circulation 2008.

[16] Straczek C, Oger E, Yon de Jonage-Canonico MB, Plu-Bureau G, Conard J, Meyer G, et al. Prothrombotic mutations, hormone therapy, and venous thromboembolism among postmenopausal women: impact of the route of estrogen administration. Circulation. 2005 Nov 29;112(22):3495-500.

[17] Canonico M, Oger E, Conard J, Meyer G, Levesque H, Trillot N, et al. Obesity and risk of venous thromboembolism among postmenopausal women: differential impact of hormone therapy by route of estrogen administration. The ESTHER Study. J Thromb Haemost. 2006 Jun;4(6):1259-65. 
[18] Canonico M, Bouaziz E, Carcaillon L, Verstuyft C, Guiochon-Mantel A, Becquemont L, et al. Synergism between oral estrogen therapy and cytochrome P450 $3 \mathrm{~A} 5 * 1$ allele on the risk of venous thromboembolism among postmenopausal women. J Clin Endocrinol Metab. 2008 Aug;93(8):3082-7.

[19] Rymer J, Wilson R, Ballard K. Making decisions about hormone replacement therapy. Bmj. 2003 Feb 8;326(7384):322-6.

[20] Utian WH, Archer DF, Bachmann GA, Gallagher C, Grodstein F, Heiman JR, et al. Estrogen and progestogen use in postmenopausal women: July 2008 position statement of The North American Menopause Society. Menopause. 2008 JulAug;15(4 Pt 1):584-602.

[21] Rexrode KM, Manson JE. Are some types of hormone therapy safer than others? Lessons from the Estrogen and Thromboembolism Risk study. Circulation. 2007 Feb 20;115(7):820-2. 